\title{
PLATEAU OF BRITISH EAST AFRICA ${ }^{1}$
}

\author{
BY GEORGE LUOIUS COLLIE
}

(Presented before the Society December 30, 1911)

\section{CONTENTS}

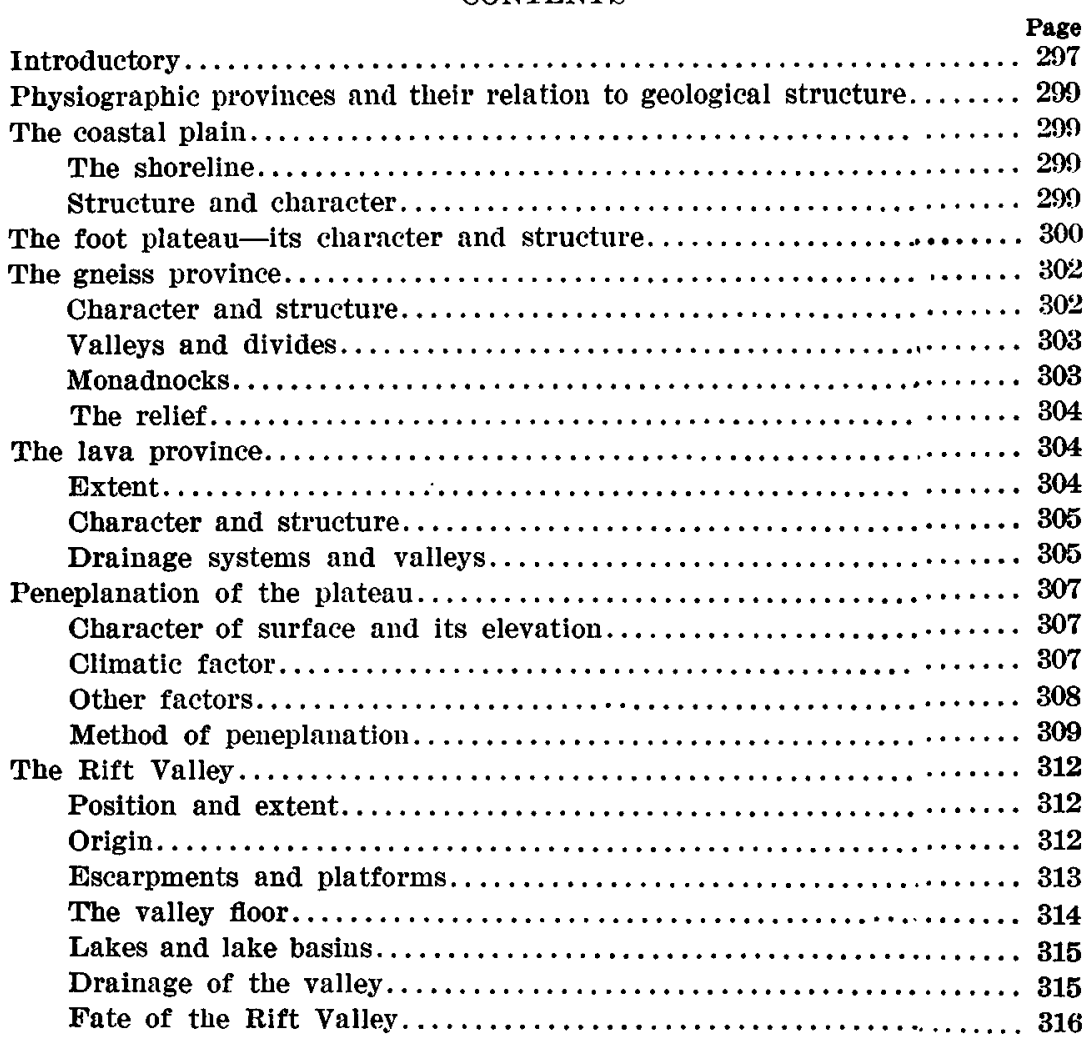

\section{INTRODUCTORY}

The observations embodied in this paper were made along the route of the Uganda Railway during the months of July and August, 1910.

1 Manuscript received by the Secretary of the Society January 29, 1912. 
Somewhat extended journeys on foot were made in each of the physiographic provinces of the area. No long trips were taken away from the railroad, however, nor were they possible except by organizing a safari, a method of travel beyond the author's means. Longer trips into more remote regions would have brought out many added details and doubtless some modification of statement, but it is not believed that they would have changed materially the conclusions of this paper.

'The area to be discussed in the following pages is a portion of the great plateau of central Africa. A brief summary of the conditions obtaining in this relatively unknown region should be given at the outset, that there may be a clear understanding of the plateau and of the problems connected with its development.

The foundation of the whole area under consideration is an ancient, gnarled, and foliated gneiss which forms the surface rock over wide stretches of the central portions of the plateau. The region has been peneplained and exhibits two cycles of erosion. The surface of the plateau is strongly graded and slopes to the eastward. The average rise from the Indian Ocean to the summit of the plateau west of the Rift Valley is about 20 feet to the mile. The eastern portion of the region has been depressed below sealevel, and upon it a series of clastics has been deposited, these rocks being mainly Mesozoic in age. The coast has passed through a number of minor oscillations since that time. The western part of the plateau has been covered by floods of lava, which have come from the present site of the Rift Valley, the earliest of these lavas being probably of early Tertiary age.

Either during or following the extrusion of the lavas there occurred the trough faulting which resulted in the formation of the great graben known as the Rift Valley, the most remarkable feature of its type in the world. The Nile basin has been excavated out of the plateau, and erosion is still attacking the western face and causing a marked eastward retreat, which will ultimately result in the obliteration of the rift and the addition of its present area to the drainage system of the Nile.

In this paper it is proposed to describe the plateau and to consider its problems under three heads, as follows:

A. A description of the country as an example of the relation of geological structure to topography.

B. A discussion of the possibility of peneplanation at high altitude without any stage of high relief. This question at present must have a theoretical aspect, yet it deserves careful study and thought. The conditions on the high plateau of Africa indicate the possibility of reducing the level of a country from a high altitude to a low without any stage of marked relief. 


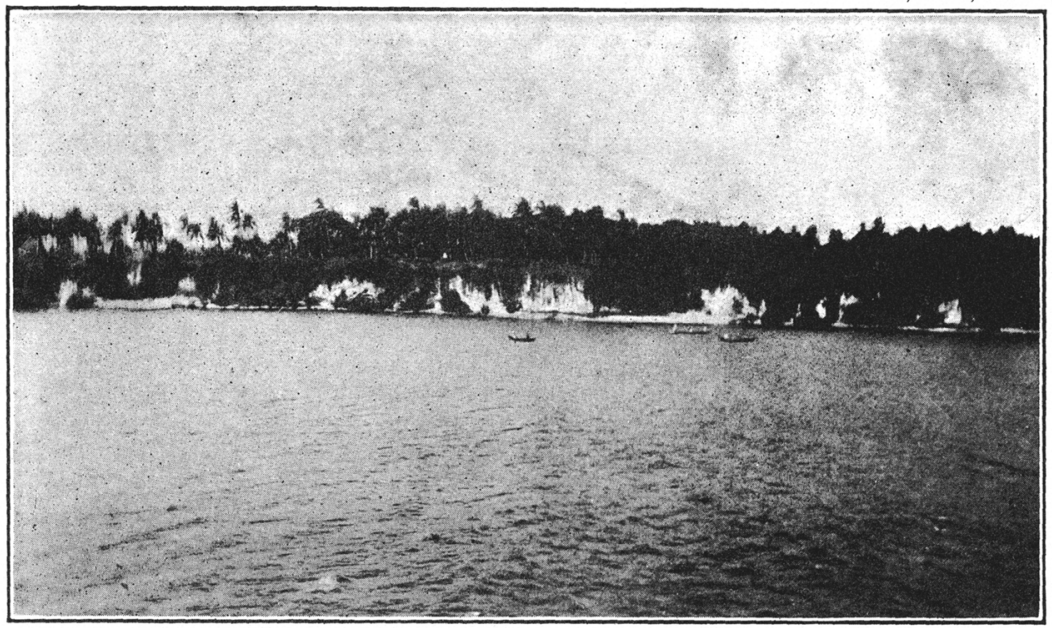

Figure 1.-Coastal Plain at Mombasa

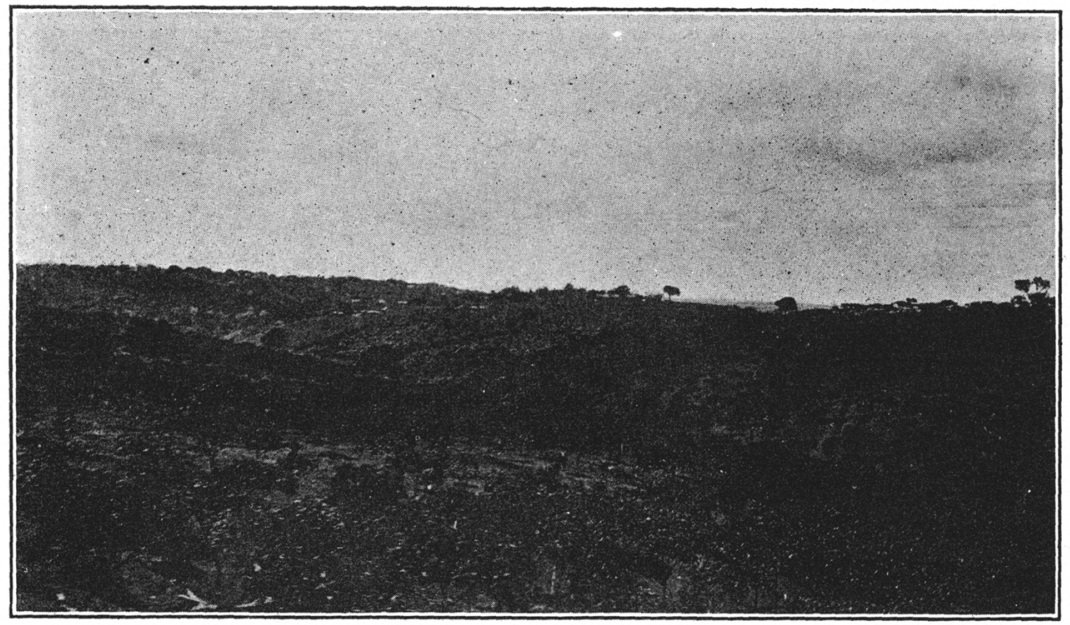

Figure 2.-Topography of the foot Plateau, near the Coast THE COAST REGION 
C. The Rift Valley is described as an example of an unusual and peculiar physiographic type.

\section{Physiographic Provinces and their Relation to geological Structure}

Five provinces may be recognized, extending in long, comparatively narrow belts in a northerly-southerly direction. They are as follows: 1. The coastal plain. 2. The foot plateau, an uplifted Mesozoic coastal plain. 3. The gneiss province. 4. The lava province. 5. The Rift Valley. The rift lies wholly within the lava province, but it is such a pronounced feature that it deserves treatment by itself and under a separate head.

\section{The coastal Plain}

\section{THE SHORELINE}

The coastal plain is a narrow belt of recent coral rock, possibly of Pleistocene age. The plain averages a width of 3 or 4 miles and is about 30 feet above mean tide, on the average. It presents a cliff frontage to the sea generally and the cliffs have been eroded into fantastic forms by the ocean. Wherever there are coves or in the neighborhood of streams beaches occur. Generally they are small pocket types, but in some instances they are extensive and front the shoreline continuously for miles. Below the base of the cliffs, partly exposed at low tide, there is frequently a wave-cut rock terrace of varying width.

On the whole, the coast presents a smooth outline; the irregularities are due mainly to the coral reefs and to the drowning of the stream deboucheres. The coast is young and wave erosion has not made serious inroads upon it as yet. Outside the present shoreline, fringing and barrier reefs are forming in great numbers. In general they lie parallel to the coast, and some of them are so close to the surface that sand is accumulating upon them; this is true even of barrier reefs several miles from land. A slight elevation would extend the shoreline seaward for some miles. The east coast of Africa is one of the great coral belts of the world. From Somaliland-with few interruptions, as off the mouth of the Zambesi River--to the neighborhood of Delagoa Bay, a distance of 2,000 miles or more, the prevailing coast formation is coral.

\section{STRUCTURE AND CHARACTER}

The coastal plain is largely one of marine denudation, but in many localities bordering the lagoons there occur beds of more or less consolidated derivative coralline sands, succeeded by beds of loose quartzose sand and gravel, the latter derived probably from the gneiss formation 
of the interior. All of the formations, whether resulting from degradation or aggradation, combine to form the low-lying, flat, featureless coast plain, ranging from 2 to 10 miles in width. The surface of the plain is covered by a thin residual soil on which a luxurious tropical forest subsists. The coral rock which underlies a greater portion of the plain is usnally quite porous and brecciated. Rainfall sinks into it rapidly and seeps away to the sea; there are few streams as a result.

In some cases small rivers originating in the interior cross the plain; they generally have short courses and few tributaries, and have had but little effect upon the topography. Their lower courses are drowned, causing irregular and widely expanded estuaries, such as form Mombasa and Kilindini harbors, the latter one of the great and splendid harbors of the world.

The sand and gravel beds of the coast plain are easily eroded, and are well dissected by ravines a few hundred yards in length. The lower courses of these ravines are depressed and become the seat of delta-like deposits, the tidal portion of which is covered with mangroves, while the
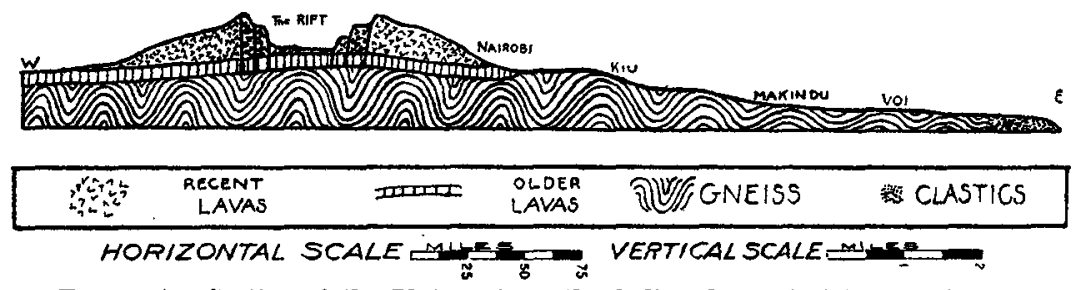

Figrir: 1.- Section of the Platean from the Indian Ocean to Victoria Vyanza.

upper part, above the tide, is used by the natives for their banana shambas. The ravine floors pass beneath the surface of the water. The 10fathom contour in the lagoons is frequently notched opposite some of the larger ravines, suggesting that they have a submarine extension. It seems probable that the land has stood at least 60 feet higher than at present within recent time. If the conjecture of Muff, ${ }^{2}$ Gregory, ${ }^{3}$ and others is correct that the coralline sands are Pleistocene, then the uplift must have taken place late in that period or subsequently. The present depression, which is the last phase in the diastrophic history of the coast, must be very recent, if not now in progress.

\section{The Foot Plateau-its Character and Structure}

Gregory uses the term foot plateau for the narrow and relatively steep front of the plateau, which faces the Indian Ocean. He limits it to that

${ }^{2}$ H. B. Muff : Col. Rep. No. 45. London, 1908.

s J. W. Gregory: The Great Rift Valley. London, J. Murray, 1896. 
portion underlain by shales; but, as there is a large scries of selimentaries underlying the shales, there seems to be no reason for discrimination between the shales and the underlying clastics from a physiographic standpoint. It seems best to consider all that portion of the plateau covered by sedimentaries as one province, under the title of foot plateau.

The sedimentary rocks of the coast, according to Muff, are as follows, in the order of their occurrence :

Raised coral reefs and Pleistocene sands (Kilindini sands).

\section{Unconformity}

Changamwe shales, limestone at the base.

Mazeras sandstones, pisolitic limestone near the top.

Mariakani sandstone.

Maji ya Chumvi bers.

Taru grits.

Gneiss.

\section{Unconformity}

The clastic rocks have been laid down conformably one upon the other, and have been uplifted, tilterl, beveled as one common unit. Their age ranges from the Carboniferous (?) to the Jurassic. The shales, which are the youngest of the series, it seems quite certain from fossil evidence, are late Jurassic. The foot plateau has been canted over, depressed beneath the sea, and uplifted, and it is simply a raised constal plain of Mesozoic age.

The plateau rises with some abruptness from the water level to a lheight of 200 feet. This slope, as already indicated, is an old sea cliff; at its base is a wave-eroded platform of varying width cut in the coral rock. The shales which lie exposed on this platean front are soft and easily weathered, thin bedded and thoroughly jointed, and are easily acted upon by erosive agents. This portion of the area is, as a result, maturely dissected and presents a series of round, knobby hills with steep slopes, separated by numerous ravines.

The work of erosion is performed quite largely by intermittent streams, which have pushed their way headward into the interior from the coast plain for a distance of 20 miles or more. The larger ravines lie 100 feet below the inter-ravine spaces; numerous side rarines have been developed, the whole forming a minute dendritic pattern.

To the west of the shales are the older and coarser clastics; these grits and sandstones are harder and more compact than the shales and they have a different topography. The transition from the shales to the sandstones is announced topographically by a relatively steep escarpment, 150 feet high on the average, known as the Nclunguni Hills. Differential 
erosion has removed the softer shales and left the harder sandstone outstanding as a prominent ridge, a notable object in the landscape as one approaches the African coast.

In this sandstone and grit belt the country becomes a flat plain of low relief, in marked contrast to the shale belt. The region has every appearance of peneplanation. It has very shallow valleys, as a rule, and they are occupied by intermittent streams. The valleys are wide, with long, sloping sides, while at the bottom there is a stream channel made during the previous rainy senson. This channel is usually a steep walled ditch marle in alluvium, and only a few feet in width or depth. The largest permanent stream observed on the foot platean is the Mwachi, with well-developed entrenched meanders 250 feet below the general level of the country. The entrenching represents a period of uplift probably to be correlated with that in which the basins of the coast lagoons were eroded during the later Pleistocene. The entrenching is marked only near the coast; a few miles inland it has disappeared; the diastrophic movements which caused it must have been relatively local. On the peneplained portion of the foot plateau the few streams which occur are almost invariably consequent upon the strong seaward slope of the plateau. A few short subsequent streams have been developed along the strike of the eastward-dipping rocks, but these as yet are of small moment. All of these streams have the characteristic wide valley with its gently sloping sides. The valley sides are rarely dissected to any extent; indeed, they are hardly to be characterized as erosion slopes in the common acceptance of that term. They are soil-creep slopes or sheet-flood erosion slopes; that is, slopes degraded by planation processes rather than by concentrated drainage.

Much of this portion of the foot plateau is covered by a thick, almost impenetrable thorny scrub; it is a desolate, uninhabited region, forsaken alike by man and beast.

\section{'Tine Gneiss Province}

\section{CHARACTER AND STRUCTURE}

Throughout the middle portion of East Africa, gneiss is the country rock. It was the original massif of the continent; the total width of the belt is 200 miles. It is a peneplained region, with numerous residuals of gneiss. In local areas there are lava flows which proceed from fissures or from mound-like volcanic cones. Generally speaking, this region, like so much of central Africa, is exceedingly monotonous, and one is overwhelmed not so much by the wide expanse of rolling plains as by their sameness mile after mile. African topography is not, as a rule, a suc- 
cession of pleasing and attractive scenery; it consists of great areas without much contrast-vast regions of one physiographic type that pall on the traveler as he journeys over them.

The gneiss is coarse-grained, extremely foliated, and exhibits rather remarkable uniformity of structure wherever it is found the foliation trends quite uniformly north-northwest south-southeast. The foliation and the coarse character of the rock indicate that the original topography was mountainous, but the mountains have been removed, for the earliest of the existing surfaces is a distinct peneplain. This early or first cycle surface is found on the Kapiti plains at an elevation of 5,300 feet. To the eastward the second cycle is well advanced and its surface lies 2,000 or 2,500 feet below the level of the first cycle surface. The original plateau represented by this higher surface apparently reached its culmination in the region of the present Rift Valley. It had seemingly gentle slopes eastward and steeper ones to the west. These slopes are inferred from the fact that the vast lava extrusions in the neighborhood have flowed both eastward and westward from the Rift region.

The original height of the plateau must have been from 8,000 to 10,000 feet, judging from altitudes now remaining as remuants on the Kinakop and Mau portions of the plateau.

\section{VALLEYS AND DIVIDES}

On the eastern border of the gneiss belt the plyssiography is not materially different from the region immediately preceding it. It is at the outset a level, monotonous region of small relief, with broad, shallow, flat-floored valleys and ravines.

The country is all slopes, and every drop of rain that falls has some long debris-laden incline at hand down which it may travel, but there are no sharply incised stream valleys. The existing valley floors and sides are covered with thick alluvial soil, for the most part, and aggradation is effective as a topography-maker.

\section{MONADNOCKS}

Beginning in the region of Maungu and extending to Kiu, monadnocks are a feature of the physiography; they are typically shown in the region of Voi. In general the gneiss residuals are ridges which lie parallel to the foliation of the gneiss. Some of the monadnocks have steep and precipitate sides; in some cases they are evidently fault-scarps; in other instances the slopes are gentle, consisting of talus slopes with slightly concave surfaces which lead away from the residuals to the general level 
of the country. The monadnocks of high altitude are deeply eroded; their sides are gashed by ravines which reach from summit to base. The greater precipitation at the summits is the reason for this condition.

In the Voi-Makindu region erosion has gone on to such an extent that the monadnocks form barely 10 per cent of the total area. In the region of Kiu they are much more numerous and closer together, and here fully one-half of the region remains comparatively unattacked.

\section{$T H E R E L I E F$}

At the eastern border the gneiss plateau is 1,100 feet above the sea; near Kapiti plains, where the lava flows begin to cover the gneiss, the elevation is 5,300 feet; the average rise is 21 feet to the mile. For the first 50 miles, until Voi is reached, the average rise is only about 15 feet to the mile. From Voi to Tsavo there is a drop of 300 feet, 'Tsavo being located in a depression probably of tectonic origin. From Tsavo to Makindu the rise is 24 feet to the mile; from Makindu to Kiu, the latter in the more uneroded portion, the average gradient is $30 \mathrm{feet}$; from Kiu to Machakos Road the average rise is 100 feet to the mile.

As has been indicated, the gradient of the plateau is greater than ought to be expected from normal erosive processes. It suggests again that tectonic movements have helped to make this relatively large gradient. In general the gneiss plateau has a thick soil, alluvial in the shallow valleys and residual on the divides. The country is open and parklike; trees and bushes of semi-arid types abound in most localities. Recent lava flows sometimes cover the gneiss locally; they smooth off even the faint relief of the gneiss, as about Simba, where thin flows spread out from small volcanoes and cover the country to quite an extent. On the other hand, near Kenani the Ndunga and Yatta flows of volcanic origin enhance the relief of the region. These hills have a sharp rectangular outline, which stands out in marked contrast to the flowing outlines of the gueiss hills. The Ndunga hills form a remarkable mesa 170 miles long and but 4 miles wide; the lava which formed the flow came from a fissure of the same length, according to those who have examined the region.

\section{The Lava Province \\ EXTENT}

This great region extends from the Kapiti plains to Victoria Nyanza, a width, measured directly, of 180 miles. The lava belt is of unknown length, but extends across British East Africa far north into Abyssinia 
and south into German East Africa. The lava flows are probably coextensive with the Rift Valley itself, and the great lava area formed by them is likely to prove on investigation to be the most extensive one on the globe. It is estimated that lava covers 150,000 square miles in British East Africa alone. Of this area, the lava province on either side of the Rift Valley covers one-half.

\section{CHARACTER AND S'TRUCTURE}

The lava province is divided into an eastern and western portion by the Rift Valley, which crosses it from north to south. The eastern or Kikuyu field is about 60 miles in width, and includes all that portion of the lava area between the gneiss area and the Rift. The lavas belong to two distinct periods; the earlier lavas are generally the more basic in composition, and they are also more deeply weathered and leached than the later lavas. The younger lavas are acid types allied to rhyolites and phonolites; generally they are quite fresh in appearance and show relatively little weathering. The older lava flowed the farther from its source and extends beyond the range of the later extrusions. On the eastern border of the Kikuyu field the lavas are the more ancient type; here they form thin beds, which scarcely mask the old peneplained gneiss surface. The Kapiti and Athi plains, with their very flat, prairie-like surfaces, are formed by these old sheets. Farther west, in the vicinity of Nairobi, great volumes of more recent lavas have swept down from the Rift region, effectually covering the previous deposits and introducing another and bolder type of topography, with strong slopes and deep, ravine-like river valleys.

The western or Nandi region has a width of about 60 miles on the average, and extends from the west side of the Rift to the shores of Victoria Nyanza. Unconsolidated pyroclastic material is abundant over the surface, but the lavas are much the same type as in the Kikuyu field, and occur as there in two distinct periods. Some of the earlier flows reach the shore of the great lake, while the more recent flows fall short by several miles, presenting steep, terrace-like fronts to the lake. Both types of lava flow around and partially cover old granitic ridges and peaks.

\section{DRAINAGE SYSTEMS AND. VALLEYS}

On the older lava fields of the Kikuyu region there are a few inconsequent streams which come down from the west from the higher portions of the plateau. The valleys are wide and shallow, the interstream spaces are broad, and there is little relief. On the divides the soil is thin and 
the underlying rocks are frequently exposed; everywhere residual boulders of lava cover the plains.

The newer lavas have been poured forth in such abundance that they have destroyed the previous drainage and imposed new conditions. Steep slopes have been made, extending from the Rift out upon the Athi plains to the east. The average gradient of the old lava slopes is three feet to the mile, while that of the new lavas is 75 feet.

The introduction of these new slopes served to bring in a new drainage scheme. The streams flow down slopes in courses of remarkable parallelism, and they are all true consequent streams-consequent upon the slopes determined by the flow of the lava. In their upper courses the streams are actively eroding; they flow in $V$-shaped valleys that reach depths of 100 feet or more. The sides of the valleys, though steep, rarely show outcrops; there is usually much fine soil, partly residual, partly volcanic dust. Numerous ravines are developed on the valley slopes, and these reach back into the flat, relatively narrow interstream spaces. The country is well dissected, though it has not yet reached maturity. The streams flow across a succession of hard and soft lava beds. In the softer rocks, wille open, amphitheater-like valleys are formed. The streams tend to be ponded by waste, with the result that small lakes and marshy areas abound. In the harder beds the valleys are narrow, georgelike, and ungraded. Near the Rift the valleys become narrower and deeper, and there is a great development of ravines, which are forcing their way back into the Rift itself, and which some day they are bound to penetrate and to drain.

On the Nandi side the drainage conditions are somewhat different. The descent from the Rift to Victoria Nyanza is about 4,350 feet-an average of over 70 feet to the mile. The rainfall is about 60 inches annually. Under these conditions erosion is a tremendous factor.

The comparatively narrow divide between the Rift and the Victoria basin is being attacked with vigor, especially from the west. On the western slope at the very outset there are deep, intricate ravines uniting to form permanent streams. Dissection has become mature, though numerous buttelike residuals remain scattered over the face of the country. There is everywhere in this area a tumult of divides and deep valleys, spurs, ridges, crests, amphitheaters, and pinnacles. The V-shaped valleys are frequently 500 feet in depth. About half way to the lake, in the region about Fort Ternan, the country is more maturely dissected and fewer residuals occur. The valleys are wider and more shallow; this is increasingly the case as the lake is approached. Finally the valley 


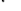




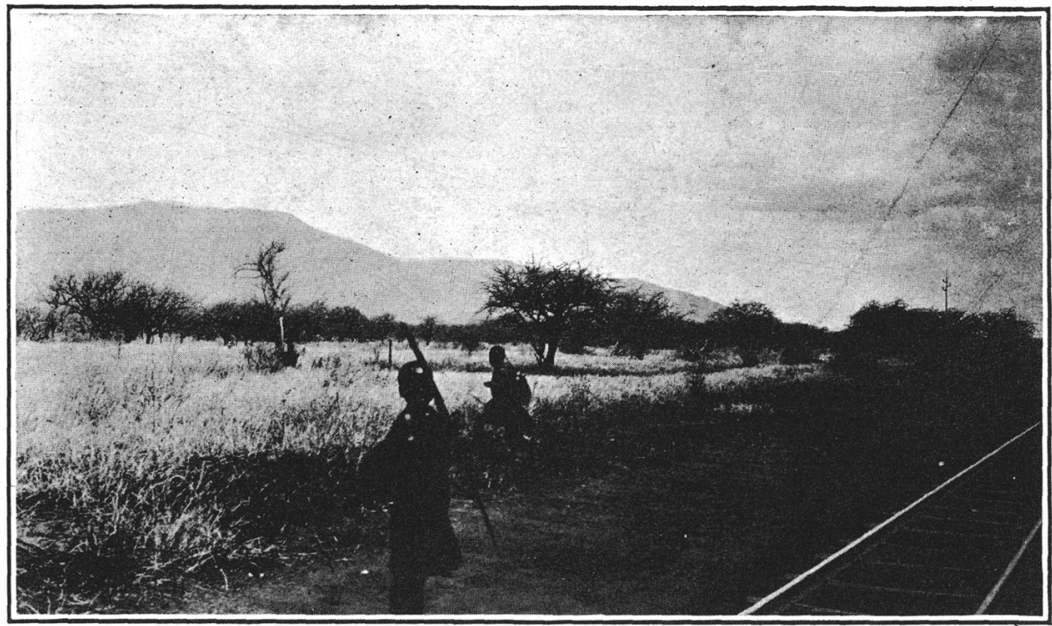

Figure 1.-MONADNOCK, NeAR VoI

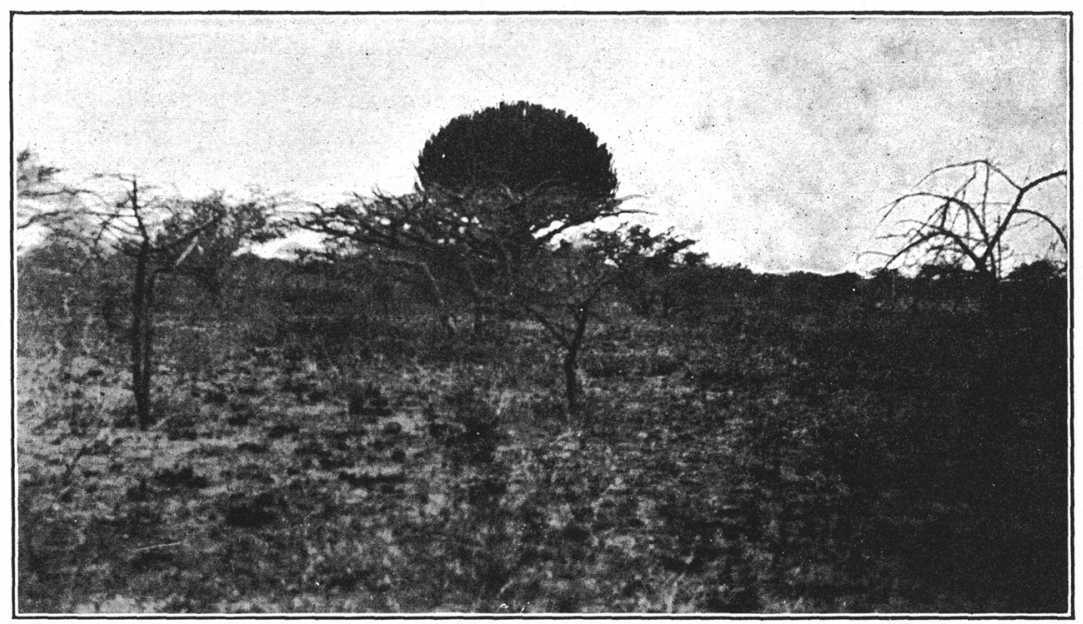

Figure 2.-Detail of Surface on the High Plateau : Makindu THE PLATEAU REGION 
walls disappear and the rivers flow ont on great alluvial fans and make their way over them into the lake.

Peneplanation of the Plateau

CHARACTER OH'SURHACE AND I'TS ELEVATION

'The most notable feature of the plateau is its peneplained condition; the surface is beveled in a marked way and without reference to foliation or other rock structures. The plateau surface has a strong gradient developed by the peneplaining activities; this gradient slopes toward the ocean as if the sea had in some way controlled its development. The gradient, while averaging 18 to 20 feet to the mile, is by no means uniform, but varies in such a way as to suggest that there have been a series of tectonic basins or platforms connected with each other by slopes or scarps. It may be that the plateau was broken up into a number of great fault-blocks at one stage of its history. If so, the scarps and other irregularities have been smoothed down or removed by erosion and the whole surface graded to the fairly uniform slope that now exists.

Much of the plateau lies at an elevation of several thousand feet above sealevel. Under normal conditions, at such altitudes there would be marked relief developed, as, for example, in the case of stream valleys. The plateau, however, lacks these elements of relief; indeed, over much of its more arid parts deep valleys are conspicuous by their absence.

It seems probable that the plateau is being peneplained at high altitudes, without reference to sealevel or without the aid of stream erosion, at least in any large measure. As this method of peneplanation differs from the normal method, it is necessary to consider the factors entering into it. Of the various factors, the principal one is the climatic one. Other minor ones are the depth of the water table, texture and structure of the rocks, absence of high mountain ranges to furnish constant supplies of water for through trunk streams.

\section{CLIMATIC FAC'I'OR}

The climate apparently lias a more important bearing on the question of peneplanation than any other factor. From the climatic standpoint it is possible to divide the country into zones parallel to the coast. The rainfall at the coast and for 30 or 40 miles back is about 32 inches annually, though this amount fluctuates greatly. Then follows a belt about 275 miles wide in which rain is scanty. In this belt, however, the higher elevations, such as the summits of the monadnocks and the more elevated 
portions of the plateau to the west, receive more rain than the plains below.

To the west of this arid belt, toward the Rift on the high plateau, the rainfall is about 42 inches per year. The Rift forms a narrow but arid belt, depressed below the plateau from 1,300 to 2,000 feet.

Here the rainfall is scanty, and this belt is, on the whole, the driest of the whole regjon. Passing over the clivide that separates the Rift from the basin of Victoria Nyanza, an annual precipitation of 60 inches is found. There are, generally speaking, two rainy seasons; the greater rains fall from March to June, the lesser rains in November and December. The two wet seasons are thus separated by months of dry weather, during which the soil becomes parched, vegetation dries up, and arid conditions prevail. 'Thus the dimatic conditions are such that there is a broad semi-arid belt, flanked on the east and west by narrower belts of rainfall. 'The east and west sides of the plateau, as a result, are seats of erosion, while the middle portion is a region of aggradation, on the whole. When the seasonal rainfall has ceased, the ground water near the surface is rapidly evaporated in the dry, hot climate which succeeds.

\section{OTHER FACTORS}

The water talse lies at a great depth over much of the plateau in all probability. In a few instances, where wells have been drilled, it is found at a depth of 600 or $: 00$ feet.

The rocks of the plateau in general contain a great many structural planes. Many of the rocks are porous and coarse-grained, and these conditions naturally facilitate the withdrawal of water to a depth.

There are no ranges of high mountains on the plateau which might furnish snowfields and glaciers for the constant supply of water through the dry seasons. (ne or two of the large volcanoes on the plateauKenia, for instance-are of such great height and size that they are able to maintain living rivers throughout the year-rivers which have volume enough to reach the sed. The 'Tand hiver flows from the Kenia region and reaches the ocean, but its course lies far outside the area deseribed in this paper, and this exreptional stream can have little bearing upon the development of the plateau as a whole. The absence of mountain ranges preclucles the existence of trunk streams, and hence it is that in this portion of Africa little of the interior drainage is able to make its way to the sea, or it does so only in an intermittent fashion, because it has no backing.

The various factors mentioned above all combine to form a type of peneplanation in which stages of great relief are lacking, because stream 
work and corrasion are minor factors, the leveling work being performed by other agencies than streams.

\section{METHOD OF PENEPLANATION}

Putting the work of these factors together as they seem to operate, the method of peneplanation appears to be as follows: During the two rainy seasons of the year there are short, sharp showers, which fall on a deep soil from which moisture has becn almost wholly removed by evaporation during the previous dry season. A part of the precipitation is readily taken into the ground and sinks down to join the deep water table. Intake of water is relatively large, for the underlying formations are not at all water-logged, and they can store all the water offered to them.

'The run-off is depleted by this large withdrawal of ground water-so much so that it becomes speedily clogged by the great amount of dry, fine dust which has accumulated in the previous months of arid weather. There can be little concentration of run-off under these circumstances; it tends rather to move off down the slopes in sheetflood manner. The sides of the shallow ralleys are very smooth, and their condition indicates that sheetflood work is important in developing them. As these overloaded sheets of water reach the valley bottom they form streams clogged with waste and incapable of doing much corrasion. 'The tendency is to aggrade rather than to corrade, and the valleys are deepened but slowly.

Corrasion barcly keeps pace with the general degradation of the country; at least it does not keep much ahead of it, and the deepening of the valleys does not gain materially on the general lowering of the region. Under such circumstances there will be little relief developed and peneplanation will go on without it.

During the dry season deflation becomes something of a factor, for the elimate is truly arid for the time being. The seasonal winds are rather light and fluctuating, and are not very important in removing dust. On the other hand, there are numerous small local whirlwinds, which take p]ace in the middle of the day over much of the plateau area, and they raise great quantities of dust high in air and bear it away to other localities. 'This deflation, together with the sheetflood erosion and possibly soil creep to some extent, are the agencies chiefly concerned in general degradation and in offsetting the feeble work of corrasion. Some corrasion takes place each year, and notably in the exceptional years when there is large general rainfall over the whole plateau; yet, as has been stated, it is never great enough to develop deep valleys nor to gain much over the general lowering of the surface. 
In spite of different rock formations and of differing climatic conditions, the whole plateau is quite uniformly graded from ocean to summit near Victoria Nyanza. It is difficult to explain this rather uniform gradation in a satisfactory way, for it looks as if some one factor controlled the whole peneplanation, and that factor was the ocean. It is not easy to understand how the ocean, as baselevel, could control peneplanation on the high plateau, where arid conditions prevail, where deflation is important, and other factors are operative which are not controlled primarily by the sea.

The best explanation to be given is as follows: The ocean as a baselevel does control the outer belt of the plateau in proximity to it. This belt in turn does exercise some influence on the semi-arid belt which adjoins it to the west. The gradation of the outer belt is wholly carried on by normal erosion, and the amount of this gradation determines how much material may be carried out from the semi-arid belt at any given time and especially in those infrequent years when streams are able to leave the dry region and reach the sea because of heavy rainfall in the interior. There is always the possibility that material may be carried seaward from the interior. The amount that is to be carried in the favorable years will clepend quite largely on the grades that exist on the outer humid belt down which the detritus from the semi-arid region must pass. In this way the outer humid belt has some control over the development of the wide, semi-arid belt of the interior. In turn the semiarid belt controls the rate and kind of degradation on the wet belt of the high plateau to the west. There is abundant precipitation on this high plateau, and it is being degraded by the numerous streams which cross it.

These streams flow out on the dry belt of the plateau, where they wither and deposit their load as a result. $A$ grade is consequently developed between the wet belt and the dry belt, a grade that can not be changed materially execpt through the cooperation of the semi-arid part of the platean. In other words, the wet belt of the high plateau can not be degraded any faster than the semi-arid belt permits. There tends thus to be adjustment between all parts of the plateau in spite of elimatic and other differences.

In the semi-arid belt there are numerous residuals, chiefly of gneiss. Rainfall is fairly constant and abundant on the summits of the higher monadnocks, and they are being lowered by normal erosion down to the level where the arid conditions set in. When the normal erosion ceases or is largely checked, then the residuals are lowered no faster than the general region, and they thus tend to be preserved indefinitely.

The second or lower cycle of erosion on the plateau is being developed 
chiefly by deflation and sheetflood work. The first cycle, represented by the higher portions of the plateau and the summits of the higher monadnocks, is being developed by normal methods of erosion. All of the debris carried from the first cycle surfaces must finally be deposited on the second cycle surfaces below; hence degradation of the first cycle can not go on more rapidly than conditions on the second cycle surface will permit. If the second cycle surface is being rapidly degraded by the agencies operating there, then opportunity is furnished for the carriage of more debris from the first cycle surface and it is swept down readily, and degradation is thus accelerated on the first cycle surface in turn. The reverse is true if degradation is inactive on the second cycle floor.

The present topography of the semi-arid belt indicates forcefully that peneplanation takes place at high altitudes without the development of great relief. This type of peneplanation has been called an arid type, but the conditions in East Africa show that it may take place where rainfall is fairly abundant, provided it comes in widely separated seasons. Aridity is perhaps the great factor, but the conception of aridity must be broadened to include not only conditions where rainfall is scanty, but also those where it comes seasonally; and, under the latter case, where it falls in short showers with sufficient intervals to permit the soil to dry out between showers. Aridity the year around and aridity for a part of the year each will produce this type of peneplanation. It is not solely a question of the amount of rainfall, but of its distribution as well, and especially is it a question of its concentration within the limits of a few weeks. Peneplanation of the type here discussed will go on in any region, just as it apparently is doing in East Africa, provided there is a margin of arid conditions over humid conditions year in and year out. This type of peneplain should be looked for, then, not only in arid regions, but also in any region where there are short seasonal rains alternating with more extended dry seasons.

The method of peneplanation in East Africa calls attention afresh to the dangers attending current interpretations of this phenomenon. For instance, suppose that the climate of East Africa were to change in such a way that rainfall became abundant: the present intermittent streams would become permanent, the present wide, shallow valleys would be deepened greatly, and there would be a system of deep, youthful valleys developed in a peneplained upland. Generally speaking, current opinion would interpret this condition as resulting from a reduction of the region to baselevel, then a subsequent uplift, which rejuvenated the streams and developed a new cycle in the older one. It is evident that the whole phenomena could be brought about simply by a relatively small change 
in the quantity and distribution of rainfall, without calling in the agency of diastrophism whatever. The writer has explained the peneplain in the driftless area of Wisconsin as due to the baseleveling of the region, possibly in the Cretaceous, followed by a subsequent uplift, which permitted the streams to renew their youth and to develop a second and well matured cycle within the old one. After his experience in Africa the author feels that possibly this former opinion is subject to revision, for the present conditions in Wisconsin may well have arisen simply through climatic changes.

\section{TIIE RIF' VALLeY}

\section{POSITIOV AND EXTENT}

If the supposition of Suess is correct, the Rift Valley extends from 15 degrees south to the neighborhood of Antioch, Syria, 35 degrees north latitude, a distance of nearly 3,500 miles. At its southern extremity, almost at the outset of its course, the valley forks; one portion proceeds to the northwest, while the other and main portion trends northward; it is a small part of the main valley that is here described. In this particular region the width of the valley from crest to crest is on the average about 70 miles, and that of the floor is about 40 miles.

The depth of the valley varies greatly, also, for the bottom rises and falls; there is a succession of basins separated by divides. Fault-block succeeds fault-block, and, in addition, the lava accumulations on the floor vary greatly in thickness. The depth of the valley ranges from 2,000 feet to 1,200 feet. In this region the valley lies on the very western edge of the high plateau, just before the descent into the Victoria basin begins, and the divide between the two is relatively very narrow. The western escarpment of the Rift is generally more elevated than the eastern one and it is the real summit of the whole plateau.

\section{ORIGTN}

The Rift Valley must be regarded as a vast graben or tectonic trough; the undulations of the floor and the absence of through trunk streams forbid the supposition that it is a valley of erosion. There is very little direct proof of faulting, however; it must be inferred from the scarp, terrace, and tilted block type of topography which abounds on every hand, and also from an occasional repetition of lava beds above and below a scarp. Although the valley is a true graben, yet its tectonic features have been greatly modified by vulcanism and in a lesser degree by normal erosion. Great floods of lava have swept over the floor, the sides, and the 
BULL. GEOL. SOC. AM.

Vól. 23, 1911, P̀L. 14

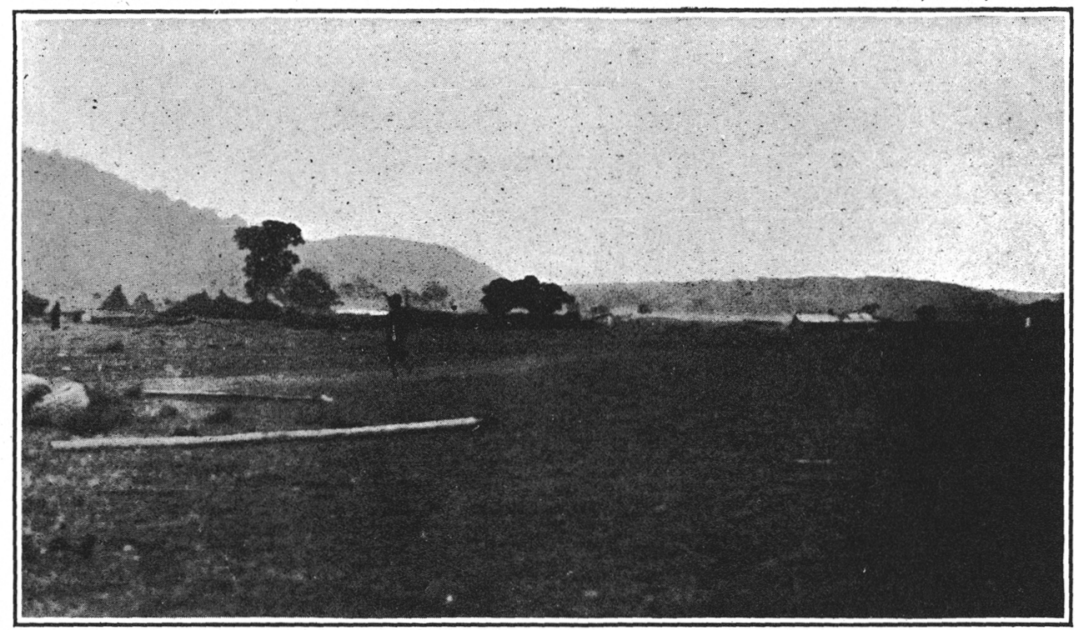

Figure 1.-The upper Scarp and Platform : Escarpment Station

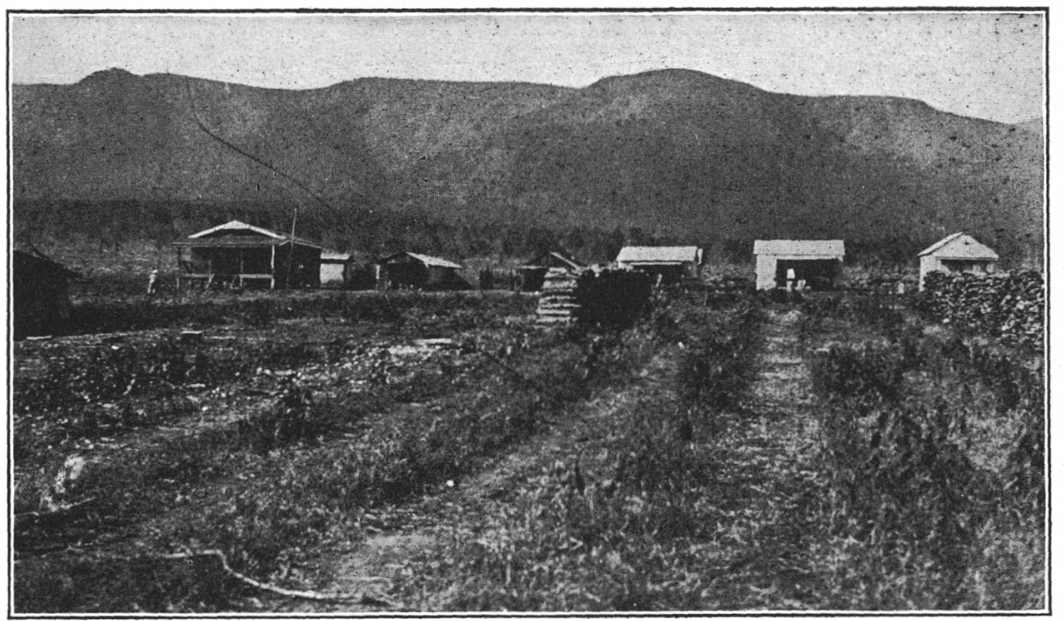

Figure 2.-The middle Scarp and Platform : KiJabe Station

THE RIFT VALLEY 
. 
approaches of the valley. The flows apparently have come from fissures which followed approximately the present course of the valley-fissures that in many cases may later have become the fault-planes of the great rift.

\section{ESCARPMENTS AND PLATFORMS}

The walls of the valley consist of a series of cliffs and platforms; they represent, respectively, fault-scarps and fault-block surfaces. The striking feature of the topography is its terraced character, exhibited on a titanic scale. The number of scarps vary. Sometimes there are but two; again there may be three, four, or even more; the normal number in this region is three. The number of scarps is determined by the development of subsidiary fault-planes, which branch out from the main fault and produce a larger or lesser number of fault-blocks, as the case may be. Where the railroad descends into the valley there are three scarps and two platforms. The total depth of the valley here is about 1,300 feet; divided between the three scarps as follows: Upper scarp, 350 feet; middle scarp, 700 feet; lower scarp, 250 feet. The height of any given scarp is not uniform, for the fault-blocks are often tilted, the throw at one end being greater than at the other; or there may be unequal subsidence in different portions of the same block. The slopes of the scarps are rarely very steep or precipitous; they usually permit the accumulation of soil. Some slopes are too steep to allow such accumulation, though talus frequently gathers at the base of such cliffs and it may reach far up the scarp face.

The soil supports a dense tropical forest on the upper heights, but vegetation becomes scanty toward the bottom of the valley, where arid conditions prevail.

The fault-planes are not straight, as a rule, but sinuous. The wall of the Rift Valley curves back and forth; the minor faults which produce the smaller blocks are generally curved, also. This curving produces blocks somewhat semi-lunar in shape, with their convexity toward the valley, as a rule. The blocks are widest in the middle and taper off at each end; generally the smaller blocks do not exceed a length of 2 or 3 miles. Frequently the blocks pitch away from the valley, but often they pitch toward it, or to the north or south. The eastern or Kikuyu wall is the steeper, and it has the more rugged and angular topography. The reason is that the rainfall is less on that side and there is far less accumulation of tuffs and other soft pyroclastics. The Nandi or west wall is the loftier, and originally the fault-scarps must have been more conspicuous there; but erosion has been so active on this side that it has worn down 
the scarps to such a degree that they are often obscure. At the same time the platforms have been aggraded by detritus brought down from the heights above. The scarps thus tend to blend more or less with the platforms, and almost continuous slopes from top to bottom result.

Only the lower scarp, which lies below the region of greatest rainfall, is clearly defined. In the neighborhood of Lake Nakuru it is a steep, definite cliff, which forms the west bank of the lake.

\section{THE VALLEY FLOOR}

The Rift Valley is an area of accumulation; no streams drain it outwardly and no debris passes from it. All of the streams entering it from the encompassing escarpments bring in large quantities of detritus, and this is gradually spread out over the valley bottom, chiefly in the form of fans. Volcanic dust and coarser pyroclastic material have drifted across the valley and collected in many depressions. The valley floor thus tends to become debris-laden; it is a great plain of aggradation, interrupted by numerous volcanic cones and lava masses.

There are a number of depressions in the floor of the valley that are generally of diastrophic origin; in some cases the lower portions of these basins contain lakes. Volcanoes are numerous, especially to one side or the other of the valley near the escarpments. Lava flows are abundant in all portions. Some of the cones have large craters; thus Suswa has a crater nearly 4 miles across and the crater of Longonot is over 2 miles across. The lava flows may be narrow coulees or broad sheets; they belong to two distinct periods, as noted in the case of the plateau lavas. Kopjes are found separated from the parent sheet; in most cases these are due to faulting, though erosion has played some part in the separation.

The volcano of Longonot is typical of the Rift Valley cones. Its base is made up of massive lava-sheets arranged in rude terraces. This basal portion is deeply weathered and represents the earlier phase of vulcanism; then follow the less eroded younger lavas. The upper part of the volcano is a great ash and tuff cone, well dissected by deep ravines, which sxtend from top to bottom; parasitic cones modify the main cone to some extent. The last phase of vulcanism in the valley was explosive in type, and there are innumerable ash and tuff cones on the valley floor, most of them relatively small in size.

In the central portion of the valley, especially near Eburru, there are numerous steam jets, hot springs, gas vents, and such evidences of recent volcanic activity. In the region between Gilgil and Elementeita the recent lavas have flooded the country; nowliere else in the region is there 
such an exhibition of vulcanism as here. Many of the massive ridges, such as the Eburru Range, are probably lava volcanoes, though their ridgelike form and the absence of cones may indicate fissure-flow genesis for these great masses.

\section{LAKES AND LAKE BAIINS}

Three of the basin-like depressions which occur in the valley contain lakes, named respectively Naivasha, Nakuru, and Elementeita. These lakes have no outlets and all are alkaline, though Naivasha is but slightly so. Two of the lakes occupy basins which lie parallel to the main tectonic lines of the valley. Naivasha is in a round basin, and is less evidently of the foregoing type. All of the lakes are shallow, and they are gradually being filled by debris brought in by the intermittent streams that flow into them. Naivasha is the most shallow of the group, its greatest depth being but 35 feet and its average less than 20 feet. There has been, probably, a period of greater rainfall in the region within recent times and the lakes have covered a much wider extent of territory than they do now, though they have not stood long enough at any given level to form definite beaches or other shorelines. Near the southern end of Naivasha there is a steep-walled gorge about 125 feet above the present level of the lake. This was doubtless an outlet for the lake at one time, when the level stood at the higher elevation indicated by the surrounding lacustrine plains.

\section{DRAINAGE OF THE VALLEY}

The higher portions of the plateau on either side of the Rift receive a much more abundant rainfall than the valley bottom does, and the streams which head up on the heights have sufficient impetus to reach the floor of the valley, though they become intermittent in the arid climate of the valley bottom. Ravines are abundant on the valley sides, and they reach from top to bottom; they even notch the crest at intervals. The upper scarps are well dissected by ravines, but the lower ones are not, for rainfall steadily diminishes from the top of the valley to the bottom. The large ravines descend the higher scarp face and pass across the first platform in narrow V-shaped gorges 100 feet deep or so; on the second scarp and platform they retain the same general form and size; thence they pass down the lower scarp and out on the floor of the valley. At the outset the ravines, as they. deploy on the valley bottom, are broad and shallow, but their sides speedily disappear and they merge into low alluvial fans, and their course is ended on these subaerial deposits.

The permanent streams are usually small and their valleys do not differ materially from the ravine type. The topography of the valley 
walls is in a youthful stage, on the whole, and the indications are that the Rift is comparatively recent in origin.

\section{FATE OF THE RIFT VALLEP}

Since the Rift is a valley of accumulation, it might become filled with detritus in the course of time, but it would take long to obliterate it by this method. Erosion, however, is removing the divide which separates it from the Victoria basin, and that with rapidity. When this divide is taken away, the warm, moisture-laden winds from the Congo region, which now precipitate their contents on the western slope of the divide, will sweep across the Rift Valley and yield their rainfall to the eastern escarpment. ' Streams will then flow across the present Rift to the Nile basin, and the Rift Valley will be added to that great system of drainage. The east wall will then be attacked and retreat until a suitable gradient has been established to the Nile. By that time the Rift will largely disappear, perhaps leaving no trace of its existence. All that may be left to tell the story of its greatness and uniqueness will be the records of those who saw it in its pristine days. 